\title{
IAMJ
}

INTERNATIONAL

AYURVEDIC

MEDICAL JOURNAL

\section{CLINICAL EVALUATION OF MEDADUSTI IN PRAMEHA W.S.R. TO ITS THERAPEUTIC MEASURES WITH MUSTAK}

\author{
Sukalyan Ray ${ }^{1}$, Apala Sengupta ${ }^{2}$, Abichal Chattopadhyaya ${ }^{3}$ \\ ${ }^{1}$ Associate Professor \& H.O.D., Dept. of Roga Nidan \& Vikriti Vijnan, \\ Raghunath Ayurved Mahavidyalay \& Hospital, Contai, West Bengal, India \\ ${ }^{2}$ Professor, Dept. of Roga Nidan \& Vikriti Vijnan, Institute of Post Graduate Ayurvedic Education and \\ Research, Shyamadas Vaidya Sastra Pith Hospital, Kolkata 700009, West Bengal, India \\ ${ }^{3}$ Professor, Dept. of Samhita \& Siddhanta, Institute of Post Graduate Ayurvedic Education and Research, \\ Shyamadas Vaidya Sastra Pith Hospital, Kolkata 700009, West Bengal, India
}

Corresponding Author: vaidya.sukalyan.ray@gmail.com

\section{https://doi.org/10.46607/iamj0509122021}

(Published Online: December 2021)

Open Access

(C) International Ayurvedic Medical Journal, India

Article Received: 10/11//2021 - Peer Reviewed: 27/11/2021 - Accepted for Publication 07/12/2021

\section{Check for updates}

\section{ABSTRACT}

Introduction: Agni (digestive and metabolic energy) is the main factor for digestion and metabolism. Meda (a type of body tissue i.e., fats) is formed from the Mamsa (a type of body tissue i.e., muscle) with its own Ushma (heat) in addition to the Snigdhatva (unctuousness) \& Dravadtva Guna (liquidity) of Apa Mahabhuta (one of the fundamental components of this universe i.e., water). Due to impairment of Dhatvagni (metabolic energy), Medadusti (impairment of fats) takes place and in turn may result in Prameha (diabetes mellitus), Sthaulya (obesity) etc. Prameha is one of the leading diseases in the present era. The aggravated Kapha afflicts Meda, Mamsa and Kleda (moisture elements of the body) and in due course of time, Kaphaja Meha (a type of Prameha) is converted into Pittaja Meha (a type of Prameha), followed by Vataja Meha (another type of Prameha) if not treated properly. Aim: The present study was carried out to evaluate the concept of Meda and the role of Medadusti in the pathogenesis of Prameha along with the efficacy of the selected drug Mustak (Cyperus rotundus Linn.) to combat the situation. Material \& Methods: In selected 35 patients of Prameha having the Medadusti Lakshan based on inclusion and exclusion 
criteria, Mustak (Cyprus rotundus Linn.) was administered in stipulated dose (12 grams in two divided doses with plain warm water) for two months. Result: The subjective parameters for Medadusti is clinically present in a maximum number of Prameha patients. The result also reveals the significant efficacy of Mustak on relevant subjective and objective parameters with a 'p-value $<0.001$ in all subjective and objective parameters. Conclusion: The Nidan (aetiology) of Medadusti has a definite role to cause Prameha. In all the patients of Prameha, Medadusti Lakshan (features of impaired fatty tissue) is clinically present. The patients suffering from Prameha can be treated with the drug response to arrest the Medadusti like Mustak.

Keywords: Medadusti, Mustak, Prameha

\section{INTRODUCTION}

Agni is the main factor for digestion, absorption and metabolism ${ }^{1}$. The root of Annavaha Srota (food channels) is Amashaya (stomach) and Vamaparsha (omentum $)^{2}$. The food provides nourishment to the tissue elements of the body, which are homologues and not contrary ${ }^{3}$. The ingested food material at first goes through digestion and is followed by absorption and metabolism with the action of Jatharagni, Bhutagni and Dhatvagni respectively. The pure and waste product of food after digestion and metabolism enter into circulation $^{4}$ through the same channel. This Dhatu (body tissue) has its channel for circulation. Food articles are composed of five Mahabhutas. Agni is specific out of these five Mahabhutas that helps in the digestion and absorption of the respective food ingredients ${ }^{5}$. By virtue of seven categories of Agni, these tissue elements get metabolized in the way of transformation of nourishing materials and transformation of waste products ${ }^{6}$.

Lipids are a heterogeneous group of fat-like substances which are water-insoluble but generally fairly soluble in an organic solvent like ether, benzene or chloroform. Simple lipid consists of three molecules of fatty acids, attached by an ester linkage to a molecule of glycerol. This large molecule is a triglyceride or natural fat. Most of the fat in a normal diet is neutral fat and any excess is stored in adipose tissue in this form. In the adult mammal, more than $10 \%$ of body weight may be stored triglycerides. Compound lipids contain other elements such as sulphur, phosphorus, nitrogen in addition to the carbon, hydrogen and oxygen simple lipids. Phospholipids are compound lipids, containing two fatty acids attached to the glycerol molecule. Instead of the third fatty acid, they have a phosphate molecule usually with an additional water-soluble molecule attached to it. This chemical constitution makes the phospholipid molecule amphipathic, with a non-polar, water-insoluble part and a high polar, water-soluble part, rest of the molecule.

Phospholipids and cholesterol are found throughout the body as part of the cell membrane and many structures that are formed from membranes, such as the endoplasmic reticulum, mitochondria, myelin sheath of nerves and the nuclear membrane. Many important compounds such as steroid hormones and bile salts are derived from cholesterol. All these types of fats are found in the blood in combination with protein as lipoproteins which act as a means of transport of the lipids. In the subsequent process, Rakta (blood) with the help of Ambu (water), Teja (energy) and Ushma (heat) is compacted and gets transformed into Mamsa (muscle tissue) ${ }^{7}$. The Sneha of the formed Mamsa is termed as Vasa ${ }^{8}$. Sneha and Drava are the qualities for which lipids are formed from fatty acids. Meda is formed from the Mamsa with its own Ushma in addition to the Snigdhatva and Dravatva Guna of Apa Mahabhuta ${ }^{9}$. Oja (the essence of all body tissues) constitutes the essence of all the seven Dhatus taken together ${ }^{10}$. Practically, Oja is the essential product of all the Dhatus, produced during specific Dhatwagni Paka (metabolic process) ${ }^{11}$ and causes the protective mechanism of the body due to its Sneha Guna ${ }^{12}$, simultaneously related to lipoprotein as Meda-Oja (the essence of fatty tissue). 
Intake of excessive Kapha aggravating diet and less physical exercise directly converts the Apakva Ahar Rasa (undigested food) into saturated fat in the body for which immunity is impaired and the nutritive channels are occluded ${ }^{13}$. The excessive intake of food - the meat and sleeping during the daytime directly vitiates blood ${ }^{14}$. The saturated fatty acid has the only single bond between the $\mathrm{C}$-atoms of the chain. Palmitic acid is the most abundant saturated fatty acid found in animal food. Saturated fatty acid usually forms solid fats, such as margarine or lard.

Unsaturated fatty acids contain one or more double bonds between the carbon chain atoms. This gives rise to geometric isomerism, known as cis-trans isomerism because of the four valance bonds of the doublebonded $\mathrm{C}$-atoms in one plane and there is no freedom of rotation about the axis of the double bond. As a result of this, there is a greater rigidity of the structure of this unsaturated fatty acid, an important determinant in cell membranes structures and function.

Altered metabolism of triglyceride-rich lipoproteins is crucial in the pathophysiology of the atherogenic dyslipidemia of diabetes. Alterations include both increased hepatic secretion of VLDL and impaired clearance of VLDL and intestinally derived chylomicrons. An important consequence of retarded clearance is prolonged plasma retention of both VLDL and postprandial chylomicrons as partially lipolyzed remnant particles. These remnants, which include cholesterolenriched intermediate-density lipoproteins (IDLs), are particularly atherogenic in humans and several animal models ${ }^{15}$.

Lack of exercise, the habit of sleeping during the daytime, excessive intake of fatty substances and excessive intake of fermented drinks like Varuni Madya ( $a$ type of alcoholic substance) vitiate Medavaha Srota ${ }^{16}$. Increased hepatic production and/or retarded clearance from plasma of large VLDL also results in increased production of precursors of small dense LDL particles. Plasma VLDL levels correlate with increased density and decreased size of LDL. In addition, LDL size and density are inversely related to plasma levels of HDL, especially the HDL subclass. The reductions in HDL associated with type 2 diabetes and insulin resistance are multifactorial, but a major factor appears to be increased transfer of cholesterol from HDL to triglyceride-rich lipoproteins, with the reciprocal transfer of triglycerides to HDL. Triglyceride rich HDL particles are hydrolyzed by hepatic lipase and, as a result, are rapidly catabolized and cleared from plasma, resulting in a low level of HDL in plasma ${ }^{17}$.

Several diseases are produced due to Medadusti, among which Prameha is the most important one. The number of people suffering from Prameha i.e., diabetes has risen from 108 million in 1980 to 422 million in 2014. In 2014, 8.5\% of adults aged 18 years and older had diabetes ${ }^{18}$. In the human body, Prameha occurs in two different pathways - one due to Dhatu Kshaya (depletion of body tissues) and another is due to Avaran (impairment of physiological process). The aggravated Kapha afflicts the Meda, Mamsa \& Kleda and produces Kaphaja Meha and likewise when aggravated Pitta afflicts the same ultimately produces Pittaja Meha. When diminution of both Kapha and Pitta occurs this led to the aggravation of Vata which ultimately gives rise to Vataja Meha following the Dhatukshaya pathogenesis if not treated properly ${ }^{19}$. On the other hand, when the path of Vata is obstructed due to several factors then the Vata together with the Ojas comes down to reach the Vasti causing Prameha to follow the Avaran pathogenesis ${ }^{20}$. In both types of Prameha, the Meda Dahtu should be considered as chief Dushya (afflicted body tissue) ${ }^{21}$.

The present study was carried out to evaluate the concept of Meda and the role of Medadusti in the pathogenesis of Prameha with modern views, along with to evaluate the efficacy of the selected drug i.e., Mustak (Cyperus rotundus Linn.) clinically on Medadusti and subsequently its role to combat Prameha.

\section{Materials and Methods:}

Medadusti is the main pathological cause in Prameha. The literary information regarding Medadusti in Prameha was verified through a clinical study. Assessment of Medadusti in Prameha was done on the basis of some subjective criteria and biochemical laboratory tests. 
The study has been also carried out to evaluate the clinical efficacy of Mustak (Cyperusrotundus Linn.) in Medadusti as occurs in Prameha.

Mustak is a known drug that is effective in Medadusti. This drug was administered to the patients included in the study to observe the improvement of subjective and objective criteria. The subjective and objective criteria were evaluated before and after treatment.

\section{Selection of Patients:}

35 patients were selected from OPD and IPD of Institute of Post Graduate Ayurvedic Education \& Research at SVSP hospital, Kolkata irrespective of their sex, occupation and religion. The patients having the Lakshan (features) of Prameha were selected for the study and subsequently, the features of Medadusti were evaluated on the basis of subjective and objective parameters. Before carrying out the study the respective ethical clearance was taken ${ }^{22}$.

\section{Inclusion Criteria:}

Patients presenting Prabhuta Mutrata and Avila Mutrata, correlated with polyuria and increased turbidity of urine (which was measured by- urine output $>50 \mathrm{ml} / \mathrm{kg}$ bd. wt. / 24 hours in comparison to water intake and analysis of urine) along with patients having Fasting Blood Sugar (FBS) $>110 \mathrm{mg} / \mathrm{dl}$ but $<140$ $\mathrm{mg} / \mathrm{dl}$ and Post Prandial Blood Sugar $>200 \mathrm{mg} / \mathrm{dl}$ but $<250 \mathrm{mg} / \mathrm{dl}$.

\section{Subjective Parameters:}

In Medadusti, though several numbers of signs and symptoms are manifested (as tabulated in table no. 2) considering the presented sign and symptoms of the attended patients of Prameha, the specific features in respect to Medavriddhi (type of Medadusti) like Snigdha Angata (unctuousness of body), Kshudra Swasa (mild respiratory distress) \& Durgandhata of Sharir (foul smell of body $)^{23}$ were considered as subjective parameters for the presented study.

\section{Objective Parameters}

Laboratory investigations for lipid profile i.e., estimation of serum cholesterol level, serum HDL cholesterol level, serum triglyceride level \& estimation of blood sugar (Fasting and PP) level were taken as objective parameters ${ }^{24}$.

\section{Adoption of the Drug:}

Mustaka (Cyperus rotundus Linn.) is a plant, which is clinically effective on Medadusti and subsequently combats Prameha by the virtue of Tikta, Katu and Kashaya rasa, Laghu Ruksha Guna and Katu Vipaka 25. Powder of tuber of Mustak (Cyperus rotundus Linn.) with plain warm water was administered in the selected patients at a dose of twelve (12) grams in two divided doses per day (i.e., 6 grams of powder in a single dose) for a period of two months. After two months, the effect of the stipulated drug was evaluated.

\section{Study Protocol: \\ Duration of study:}

The duration of the study was one and a half years.

\section{Assessment Criteria:}

The assessment was done on the basis of subjective and objective criteria before and after treatment.

\section{Follow up of Patients:}

All the patients were reviewed after two months from the date of administration of the first dose. Any special information regarding the general health of the patient was recorded accordingly.

\section{Study Sample:}

A total of 35 patients of Prameha with Medadusti were included in the study.

\section{Statistical Analysis:}

The information gathered on the basis of observation made about various parameters was subjected to statistical analysis in terms of Mean, Standard Deviation (SD) and Standard Error (SE). Paired 't-test was carried out at $\mathrm{P}<0.05$ and $\mathrm{P}<0.001$. The obtained results were interpreted as -

$\mathrm{P}<0.05$ is significant \& $\mathrm{P}<0.001$ is highly significant. Observations and Results:

Among the 35 patients, a total of 3 patients were dropped out during the study course. Hence complete clinical survey was done on 32 patients. The distribution of subjective parameters of Medadusti among the 32 patients of Prameha shows that Snigdhaangata was present in 30 patients (93.75\%), Kshudraswas present in 26 patients $(81.25 \%)$ and Sharir Durgandhata present in 31 patients $(96.87 \%$ ) [table no. 3]. Statistical analysis of subjective and objective parameters of $\mathrm{Me}$ dadusti in 32 patients of Prameha before and after 
treatment shows that Mustak has significant efficacy on both the subjective and objective parameters with 'p-value <0.001. [table no. 4].

\section{DISCUSSION}

In the present era, patients suffering from Prameha come before the physician at the very manifestation of Purvarupa (prodromal features) of Prameha as mentioned in the compendium due to their health consciousness. And subsequently, Medadusti Lakshan is identical to that of the Purva Rupa of Prameha. The term Linga or Lakshan is also implied for Purvarupa ${ }^{26}$. Considering this in table no. 2 the identical Lakshan of Medadsuti and Prameha have been tabulated ${ }^{27}$. Avyayam (absence of physical exercise) and $D i$ vaswapna (habit of the day sleeping) cause Medadusti and Prameha directly. But Medyanam Atibahkshanam (excessive intake of fatty substance) and Varuni Madya Atisevanam (excessive intake of alcoholic substance) cause Medadusti directly but indirectly they are related with the Habyishanna Bhojana (where the fat substances are maximum) and Ikshu Vikriti (sugarcane products) accordingly, thus act as a causative factor of Prameha. In the above context, the identical $\mathrm{Ni}$ dan of Medavaha Srotadusti \& Prameha has been tabulated in table no. ${ }^{28}$.

Table 3 shows that most of the patients of Prameha were satisfying the subjective criteria of Medadusti. It signifies that Medadusti is an essential phenomenon in the cases of Prameha.

Table 4 shows the statistical analysis before and after administration of the drug Mustaka (Cyperus Rotundus Linn.) This table shows the 'p-value $<0.001$ in most of the parameters (subjective and objective), which indicates that the drug taken for the present study is highly efficacious in Medadusti and subsequently in Prameha.

The probable mode of action of Mustak is given below 29:

Due to Laghu and Ruksha Guna, which are Vata \& Agni Mahabhuta Pradhana, Mustak causes Kapha and Meda Nashan. Due to Katu Rasa (Vata \& Agni Mahabhuta Pradhan) it causes Kapha Meda Nashan, due to Tikta Rasa (Vata + Aksha Mahabhuta Pradhan) it causes Kledasoshan \& Medanashan \& due to Kashaya Rasa (Vata \& Prithivi Mahabhuta Pradhan), Mustaka causes Lekhan and Kleda Soshan. Also due to Sheeta Virya and Katu Vipak, Mustak causes Vata Prakopa, which in turn causes Lekhan and Kleda Soshan. Thus, Mustak acts against the Meda Dusti.

\section{CONCLUSION}

The Nidan of Meda Dusti has a definite role to cause Prameha. In all the patients of Prameha, Meda Dusti Lakshan is clinically present. The patients suffering from Prameha can be treated with the drug response to arrest the Medadusti like Mustak.

Table 1: Showing the distribution of subjective parameters of Medadusti among the 32 patients of Prameha:

\begin{tabular}{|l|l|l|l|}
\hline Sl. No. & Subjective Parameters & Number of Patients & Percentage \\
\hline 01. & Singdhaangata & 30 & $93.75 \%$ \\
02. & Kshudraswas & 26 & $81.25 \%$ \\
03. & Sharir Durgandhata & 31 & $96.87 \%$ \\
\hline
\end{tabular}

Table 2: Showing the statistical analysis of subjective and objective parameters of Medadusti in 32 patients of Prameha before and after treatment:

\begin{tabular}{|l|l|l|l|l|l|l|}
\hline Parameters & Mean BT & Mean AT & SD +/- & SE +/- & 't' value & 'p-value \\
\hline Snigdhaangata & 1.65 & 0.56 & 0.53 & 0.0938 & 11.62 & $<0.001$ \\
Kshudraswas & 1.40 & 0.37 & 0.473 & 0.083 & 12.40 & $<0.001$ \\
Sharira Durgandhata & 1.34 & 0.37 & 0.594 & 0.105 & 9.21 & $<0.001$ \\
\hline
\end{tabular}




\begin{tabular}{|l|l|l|l|l|l|l|}
\hline FBS & 137.18 & 135.43 & 1.106 & 0.198 & 8.83 & $<0.001$ \\
PPBS & 192.5 & 183.78 & 1.26 & 0.226 & 9.81 & $<0.001$ \\
Serum Cholesterol & 211.25 & 209.96 & 0.456 & 0.082 & 15.6 & $<0.001$ \\
Serum HDL cholesterol & 72.12 & 71.81 & 0.534 & 0.096 & 13.64 & $<0.001$ \\
Serum Triglyceride & 168.87 & 166.81 & 1.91 & 0.343 & 6.00 & $<0.001$ \\
\hline
\end{tabular}

Table 3: Identical Lakshan of Medadusti \& Prameha:

\begin{tabular}{|c|c|c|c|}
\hline Sl. No. & Lakshan (clinical features) & Meda Dusti & Prameha \\
\hline 01. & Alasyam (laziness) & + & + \\
\hline 02. & $\begin{array}{l}\text { Hrid-Netra-jihva-shravana Upadeha (adherence of ex- } \\
\text { creta in heart, eyes, tongue and ear) }\end{array}$ & + & + \\
\hline & Jatilabhava Keshesu (matting of hair) & & \\
\hline 03. & Karapadoyo Daha (burning sensation in hand and feet) & + & + \\
\hline 04. & Karapadayo Suptata (numbness in hand and feet) & + & + \\
\hline 05 . & $\begin{array}{l}\text { Kaya Malam (increase amount of excreta from the } \\
\text { body) }\end{array}$ & + & + \\
\hline 06. & $\begin{array}{l}\text { Kayachhidreshupadeham (adherence of excreta in the } \\
\text { orifices of the body) }\end{array}$ & + & + \\
\hline 07. & $\begin{array}{l}\text { Kesha Nakhativriddhi (excessive growth of hair and } \\
\text { nails) }\end{array}$ & + & + \\
\hline 08. & $\begin{array}{l}\text { Mukha Talu Kantha Sosha (dryness of mouth, palate } \\
\text { and throat) }\end{array}$ & + & + \\
\hline 09. & Madhuryamasya (the sweetness of mouth) & + & + \\
\hline 10. & $\begin{array}{l}\text { Mutreabhidhavanti Pipilikashcha (attraction of ants by } \\
\text { urine) }\end{array}$ & + & + \\
\hline 11. & Madhurshukla Mutrata (sweet and whitish urine) & + & + \\
\hline 12. & $\begin{array}{l}\text { Nidra (excessive sleep) } \\
\text { Pipasa (excessive thirst) }\end{array}$ & + & + \\
\hline 13. & Paridaham Angeshu (burning sensation in body) & + & + \\
\hline
\end{tabular}




\begin{tabular}{|l|l|l|l|}
\hline $\begin{array}{l}14 . \\
\text { 15. }\end{array}$ & Sajyaasanaswapna sukham (sedentary habit) & + & + \\
\hline 16. & & + & + \\
\hline
\end{tabular}

Table 4: $\quad$ Identical Nidan of Medavaha Srotadusti \& Prameha:

\begin{tabular}{|l|l|l|l|}
\hline Sl. No. & Nidan & Meda Dusti & Prameha \\
\hline 01. & Avyayam & + & + (direct) \\
02. & Divaswapna & + & + (direct) \\
03. & Medyanam atibhakshanam & + & + (indirect) \\
04. & Varuni madya atisevan & + & + (indirect) \\
\hline
\end{tabular}

\section{REFERENCES}

1. Charak Samhita of Agnivesha with Ayurved Deepika commentary of Chakrapani Dutta. Edited by - Yadavji Trikamji Acharya, published by Chowkhamba Orientalia, Varanasi, 2009 ed. Chikitsasthan, chapter 15, sloka 43-4. page 512.

2. Charak Samhita of Agnivesha with Ayurved Deepika commentary of Chakrapani Dutta. Edited by - Yadavji Trikamji Acharya, published by Chowkhamba Orientalia, Varanasi, 2009 ed. Vimansthan, chapter 5, sloka 8. page 251.

3. Charak Samhita of Agnivesha with Ayurved Deepika commentary of Chakrapani Dutta. Edited by - Yadavji Trikamji Acharya, published by Chowkhamba Orientalia, Varanasi, 2009 ed. Sharirsthan, chapter 6, sloka 16. Chakrapani commentary page 332.

4. Charak Samhita of Agnivesha with Ayurved Deepika commentary of Chakrapani Dutta. Edited by - Yadavji Trikamji Acharya, published by Chowkhamba Orientalia, Varanasi, 2009 ed. Chikitsasthan, chapter 8, sloka 9. page 460.

5. Charak Samhita of Agnivesha with Ayurved Deepika commentary of Chakrapani Dutta. Edited by - Yadavji Trikamji Acharya, published by Chowkhamba Orientalia, Varanasi, 2009 ed. Chikitsasthan, chapter 15, sloka 13. page 514.

6. Charak Samhita of Agnivesha with Ayurved Deepika commentary of Chakrapani Dutta. Edited by - Yadavji Trikamji Acharya, published by Chowkhamba Orientalia, Varanasi, 2009 ed. Chikitsasthan, chapter 15, sloka 13. page 513.

7. Charak Samhita of Agnivesha with Ayurved Deepika commentary of Chakrapani Dutta. Edited by - Yadavji
Trikamji Acharya, published by Chowkhamba Orientalia, Varanasi, 2009 ed. Chikitsasthan, chapter 15, sloka 29. page 513

8. Samhita of Agnivesha with Ayurved Deepika commentary of Chakrapani Dutta. Edited by - Yadavji Trikamji Acharya, published by Chowkhamba Orientalia, Varanasi, 2009 ed. Sharirsthan, chapter 4, sloka 13. page 317

9. Charak Samhita of Agnivesha with Ayurved Deepika commentary of Chakrapani Dutta. Edited by - Yadavji Trikamji Acharya, published by Chowkhamba Orientalia, Varanasi, 2009 ed. Chikitsasthan, chapter 15, sloka 29. page 514

10. Susruta Samhita with Dalhan commentary, Edited by Yadavji Trikamji Acharya, published by Chowkhamba Sanskrit Pratisthan, Varanasi. $6^{\text {th }}$ edition. Sharirsthan, chapter 15, sloka 19, page 67.

11. Charak Samhita of Agnivesha with Ayurved Deepika commentary of Chakrapani Dutta. Edited by - Yadavji Trikamji Acharya, published by Chowkhamba Orientalia, Varanasi, 2009 ed. Sutrasthan, chapter 28, sloka 4. page 175 .

12. Charak Samhita of Agnivesha with Ayurved Deepika commentary of Chakrapani Dutta. Edited by - Yadavji Trikamji Acharya, published by Chowkhamba Orientalia, Varanasi, 2009 ed. Sutrasthan, chapter 30, sloka 9. page 184.

13. Susruta Samhita with Dalhan commentary, Edited by Yadavji Trikamji Acharya, published by Chowkhamba Sanskrit Pratisthan, Varanasi. $6^{\text {th }}$ edition. Sutrasthan, chapter 15, sloka 37, page 67.

14. Susruta Samhita with Dalhan commentary, Edited by Yadavji Trikamji Acharya, published by Chowkhamba Sanskrit Pratisthan, Varanasi. $6^{\text {th }}$ edition. Sharirsthan, chapter 24, sloka 5, page 124. 
15. Krauss Ronald M., Lipids and lipoproteins in patients with type 2 diabetes, Diabetes care, 2004 June; 27 (6): page 1496 - 1504. http:// dx.doi.org/10.2337/diacare.27.6.1496

16. Charak Samhita of Agnivesha with Ayurved Deepika commentary of Chakrapani Dutta. Edited by - Yadavji Trikamji Acharya, published by Chowkhamba Orientalia, Varanasi, 2009 ed. Vimansthan, chapter 5, sloka 17. page 251.

17. Krauss Ronald M., Lipids and lipoproteins in patients with type 2 diabetes, Diabetes care, 2004 June; 27 (6): page 1496 - 1504. http:// dx.doi.org/10.2337/diacare.27.6.1496

18. WHO fact sheet, Diabetes, reviewed June 2016, http:// who.int

19. Charak Samhita of Agnivesha with Ayurved Deepika commentary of Chakrapani Dutta. Edited by - Yadavji Trikamji Acharya, published by Chowkhamba Orientalia, Varanasi, 2009 ed. Chikitsasthan, chapter 6, sloka 5-6. page 445 .

20. Charak Samhita of Agnivesha with Ayurved Deepika commentary of Chakrapani Dutta. Edited by - Yadavji Trikamji Acharya, published by Chowkhamba Orientalia, Varanasi, 2009 ed. Sutrasthan, chapter 17, sloka 78-81. page 103.

21. Charak Samhita of Agnivesha with Ayurved Deepika commentary of Chakrapani Dutta. Edited by - Yadavji Trikamji Acharya, published by Chowkhamba Orientalia, 2009 ed. Nidansthan, chapter 4, Chakrapani commentary.

22. Memo no. PG/663/2012, dated 19.06.2012, Institute of Post Graduate Ayurvedic Education and Research at Shaymadas Vaidya Sastra Pith Hospital, Govt. of West Bengal, 294/3/1, A.P.C Road, Kolkata-9

23. Susruta Samhita. Ayurved Tatwa Sandeepika, Hindi commentary by Ambika Dutta Sashtri, published by Chowkhamba Sanskrit Pratisthan, Varanasi. $6^{\text {th }}$ edition. Sutrasthan, chapter 15, sloka 19, page 60 .

24. Current Medical Diagnosis and Treatment 2011 (ebook), Mc. Graw Hill. Lange. $50^{\text {th }}$ edition. chapter 19 (Diabetes Mellitus) \& 20. (Nutritional Disorders).

25. Bhavaprakash of Shri Bhava Mishra, edited by Bhisagratna Brahma Shankar Mishra, published by Chaukhamba Sanskrit Bhawan, Varanasi, Eleventh Edition, 2012, Raj Nighantu of Pandit Narahari, edited by Indradev Tripathi, Krishnadas Academi, Varanasi, 1st edition, 1982; Shaligram Nighantu, edited by Khemraj S., Stream Press, Bombay, 1981; Madanpal Nighantu, edited by Sri Krishnadas Gangabishu, stream Press, Bombay, 1954

26. Madhav nidan of Madhavkar with Madhukosh commentary of Vijayrakshit \& Srikantha Dutta, edited by Yadavji Trikamji Acharya, published byChowkhamba Orientalia, 2009 ed. chapter 1, sloka 3, commentary of Vijayrakshit, page 03

27. Charak Samhita of Agnivesha with Ayurved Deepika commentary of Chakrapani Dutta. Edited by - Yadavji Trikamji Acharya, published by Chowkhamba Orientala, 2009 ed. Nidansthan, chapter 4, sloka 13-47, also Chikitsasthan, chapter 7, sloka, page 215-217; Susruta Samhita with Dalhan commentary, Edited by Yadavji Trikamji Acharya, published by - Chowkhamba Sanskrit Pratisthan, Varanasi. $6^{\text {th }}$ edition. Nidansthan, chapter 6, sloka 10-13, page 290-292

28. Charak Samhita of Agnivesha with Ayurved Deepika commentary of Chakrapani Dutta. Edited by - Yadavji Trikamji Acharya, published by Chowkhamba Orientalia, 2009 ed. Nidansthan, chapter 4, sloka 5, page 212, also in Chikitsasthan, chapter 6, sloka4, page 445; Susruta Samhita with Dalhan commentary, Edited by Yadavji Trikamji Acharya, published by Chowkhamba Sanskrit Pratisthan, Varanasi. $6^{\text {th }}$ edition. Nidansthan, chapter 6, sloka 3-, page 289.

29. Bhavaprakash of Shri Bhava Mishra, edited by Bhisagratna Brahma Shankar Mishra, published by Chaukhamba Sanskrit Bhawan, Varanasi, Eleventh Edition, 2012, Raj Nighantu of Pandit Narahari, edited by Indradev Tripathi, Krishnadas Academi, Varanasi, 1st edition, 1982; Shaligram Nighantu, edited by Khemraj S., Stream Press, Bombay, 1981; Madanpal Nighantu, edited by Sri Krishnadas Gangabishu, stream Press, Bombay, 1954

\section{Source of Support: Nil Conflict of Interest: None Declared}

How to cite this URL: Sukalyan Ray et al: Clinical Evaluation Of Medadusti In Prameha W.S.R. To Its Therapeutic Measures With Mustak. International Ayurvedic Medical Journal \{online\} 2021 \{cited December 2021\} Available from: http://www.iamj.in/posts/images/upload/2948_2955.pdf 